\title{
Growth performance, blood parameters and production cost of broiler chickens fed dietary sweet orange peel meal diets with and without enzyme addition
}

"Sunmola, T. A., Tuleun, C. D. and Oluremi, O. I. A.

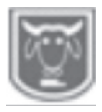

Department of Animal Nutrition, College of Animal Science, University of Agriculture, P.M.B. 2373, Makurdi, Benue State, Nigeria.

*Corresponding author: ta.sunmola@gmail.com

\section{Abstract}

The growth performance, blood parameters and production cost of two hundred and fifty two (252) Abor acre plus broiler chickens fed sweet orange peel meal (SOPM) with and without enzymes were investigated. The experimental diets consist of control $\left(T_{0}\right)$, maize was replaced with SOPM at 15, 20 and $25 \%$ without exogenous enzymes to form $T_{1}, T_{2}$ and $T_{3}$ respectively, and another supplemented with exogenous enzyme to form $T_{4}, T_{5}$ and $T_{6}$ respectively. The birds were randomly allocated to seven treatment groups replicated three times to have 12 birds per replicate and were fed experimental diet ad-libitum for eight weeks. Result showed that broiler chickens fed control diet $\left(T_{0}\right)$ had significantly $(P<0.05)$ higher final weight $(F W)$ of $2.44 \mathrm{~kg}$, weight gain $(W G)$ of 42.91, feed intake (FI) of 86.53, better feed conversion ratio (FCR) of 2.01 and protein conversion ratio (PCR) of 0.44 compared to other dietary treatments. Broiler chickens fed $T_{1}$ and $T_{4}$ had significantly $(P<0.05)$ higher final weight of 1.98 and $1.98 \mathrm{~kg}$, weight gain of 34.69 and $34.71 \mathrm{~g}$ and feed intake of 78.35 and $81.63 \mathrm{~g}$ respectively while significantly $(P<0.05)$ least values of 1.75 and $1.80 \mathrm{~kg}$ final weight, 30.73 and $31.49 \mathrm{~g}$ weight gain and 69.47 and $71.84 \mathrm{~g}$ feed intake respectively were recorded in broiler chickens fed $T_{2}$ and $T_{5}$. Haematological indices namely: $P C V, R B C, W B C$ and $H b$ were not significantly different (P>0.05) but $M C V, M C H, M C H C$, lymphocytes, heterophil, eosinophil and monocytes differed significantly $(P<0.05)$. Serum biochemical indices namely total protein, albumin, globulin and uric acid were significantly $(P<0.05)$ influenced by the experimental diets. Though, there was no detrimental effect of SOPM and enzyme on production cost as profit was made at all replacement levels of SOPM with and without enzyme treatment, but profit per bird (\#) and cost to benefit ratio revealed the superiority of the broiler chickens fed control diet $\left(T_{0}\right)$. Based on the results obtained, SOPM can replace maize up to $25 \%$ without posing any deleterious effect on the broiler chickens growth performance, blood parameters and production cost. However, the cost to benefit ratio was compromised with the use of SOPM.

Keywords: broiler; performance; orange peel; polyzyme ${ }^{\text {s }}$; blood parameters; economics

\section{Introduction}

The demand for eggs and poultry meat has significantly increased in recent years across large parts of the continent, due to the high population growth in Africa and growing income (World Health Organization, 2014). According to estimates by the USAID (United States Agency for International Development), this trend is very likely to continue over the next few years. Therefore, the consumption of poultry meat and eggs will increase by
$200 \%$ between 2010 and 2020 for some countries in sub-Saharan Africa (Obi, 2003; USDA, 2013). One African country where this trend can clearly be seen is Nigeria with estimated population of 174.5 million people in 2013 and at the growth rate of $3 \%$ per annum (USDA, 2013). The Nigerian poultry industry in particular has been rapidly expanding in recent years and is therefore one of the most commercialized (capitalized) subsectors of Nigerian agriculture (Adene and Oguntade, 2006; 


\section{Growth performance, blood parameters and production cost of broiler chickens}

USDA, 2013). Nutrition is the most important consideration in poultry industry and its survival is dependent on the availability of feedstuffs, which are mainly components of human food e.g maize (Esonu et al., 2006). However, feed cost is presently very high and makes up to $70-80$ $\%$ of the total cost of production in Nigeria compared to 50 to $70 \%$ in developed countries (Thackie and Flenscher, 1995). Several attempts have been made to reduce the cost of farm animal production by replacing percentages of maize with agroindustrial by-products such as maize offal, wheat offal, rice offal, cassava peel, brewers dried grain (Ibiyo and Atteh, 2005). A number of residue materials like peels, rag, seed (Chapman et al., 2000) are produced when fresh citrus fruits are processed into juice, concentrate and canned fruit in developed countries or when they are peeled for direct human consumption as in the case of most developing countries like Nigeria. These by-products can be processed into wet and dried citrus pulp, citrus molasses, citrus meal and citrus seed meal. Various studies on feeding value of these citrus by-products showed that citrus by-products can be utilized for monogastric animals (Oluremi et al., 2006). Nutritional trials with monogastric animals have shown that the meal of sun dried peels of Citrus sinensis can replace dietary maize in broiler chickens diet up to $20 \%$ (Agu, 2006). The present work was done to evaluate the potential use of sweet orange peel meal with and without enzymes in broilers' diets on growth performance, blood parameters and economic of production.

\section{Materials and methods Experimental site}

The study was conducted at the Poultry Unit of the Livestock Teaching and Research Farm, Federal University of Agriculture, Makurdi, Benue State. Makurdi is located between latitude $7^{0} 44^{\prime} \mathrm{N}$ and longitude $8^{0} 21^{\prime} \mathrm{E}$ in the Guinea Savanna Zone of West Africa. The area has an annual rainfall between 6 - 8 months (May - October) and ranges from 508 to $1016 \mathrm{~mm}$ with a minimum temperature range of $24.20 \pm$ $1.4^{\circ} \mathrm{C}$ and maximum temperature range of $36.33 \pm 3.70^{\circ} \mathrm{C}$. The relative humidity ranges between $39.50 \pm 2.20 \%$ and $64.00 \pm$ $4.80 \%$ (TAC, 2011).

Collection and preparation of test ingredients

Fresh sweet orange (Citrus sinensis) fruit peel was collected from orange retailers on the university campus and immediately sun-dried to a moisture content of less than $12 \%$ moisture. It was milled to obtain the sweet orange peel meal which was mixed with other feed ingredients to produce the experimental diets. The enzyme used in this study was "POLYZYME ${ }^{\circledR}$. The polyzyme contains xylanase, phytase, cellulase, $\beta-$ glucanase, pectinases, $\alpha$ - amylase, protease, $\alpha$ - galactosidase, $\beta$ galactosidase, lipase and mannanase all of which are able to digest complex carbohydrates at the manufacturer recommendation dose of $400 \mathrm{gm}$ per ton of mash feed.

\section{Experimental design and diets}

Two hundred and fifty two (252) Abor acre plus chicks (one day old) were used in the experiment. The experiment was divided into seven (7) treatments with replacement levels of 15,20 and $25 \%$ sweet orange peel meal (in partial replacement of white maize) with or without enzyme supplement and also a control. Each treatment consisted of three replicates. The experimental groups are as follows: Group $=\mathrm{T}_{0}$ : control (Control without SOPM and Enzyme), Group 2 $=\mathrm{T}_{1}$ : $15 \%$ SOPM without Enzyme, Group $3=\mathrm{T}_{2}$ : $20 \%$ SOPM without Enzyme, Group $4=\mathrm{T}_{3}$ : $25 \%$ SOPM without Enzyme, Group $5-\mathrm{T}_{4}$ : $15 \%$ SOPM + Enzyme, Group $6=\mathrm{T}_{5}: 20 \%$ 


\section{Sunmola, Tuleun. and Oluremi}

SOPM + Enzyme, Group $7=\mathrm{T}_{6}: 25 \%$ SOPM + Enzyme. The experimental diets were formulated according to the Aduku (2005) recommendations to meet the nutrient requirements of broiler chicks from day 1 to 28 (starter diet) and from day 29 to 42 (finisher diet). The starter diets contained between $22-24 \% \mathrm{CP}$ and 2800 $2900 \mathrm{kcal} \mathrm{ME} / \mathrm{Kg}$ and the finisher diet contained $20-22 \% \mathrm{CP}$ and $2900-3100$ $\mathrm{kcal} \mathrm{ME} / \mathrm{Kg}$. The gross and nutrients composition of the experimental and control diets used at both broiler starter and finisher phases are shown in Tables 1 and 2. Feed and water were provided ad-libitum throughout the 56 days experimental period.

\section{Data collection}

Feed intake was calculated as difference in the quantity of feed given and left over after 24 hour. Weight gain was determined weekly. Feed: grain ratio was calculated from feed intake and weight gain. Protein conversion ratio was calculated by multiplying feed intake by dietary protein intake divided by body weight gain. Cost of feed was calculated from the cost of ingredients used in feed preparation. Feed cost per kilogram live weight gain was calculated from feed cost and feed: gain ratio. Feed cost per weight gain was calculated by multiplying the feed cost per $\mathrm{kg}$ with total feed intake and divided by total weight gain. Feed cost/chick was calculated by multiplying feed intake per day by the number of days and by feed cost per kilogram. Operational cost per bird was calculated by adding all other expenses except expenses on feed and day old broiler chick. Cost savings due to SOPM was calculated by subtracting total cost of production of each treatment from total cost of production of the broiler chickens fed control diet. Total cost of production was calculated by adding cost of day old chick, feed cost per chick and operational cost.
Feed cost as a percentage of total production cost was calculated by dividing cost of feed per $\mathrm{kg}$ with total cost of production and multiply by hundred. Income per bird was calculated by multiply average live weight by selling price per kilogram live weight. The profit per bird was calculated by subtracting expenses from income. Cost: benefit ratio was calculated by dividing the expenses with income.

Nutrient digestibility

Determination of nutrient digestibility was done from 49 to 56 days of the experimental period. Two birds per replicate were selected and transferred into metabolic cages. A 3-days acclimatization period was allowed for the birds and the respective diets were offered liberally. Daily feed intake and daily faecal output were recorded for 4 days. The feacal droppings were collected per replicate once daily at 8:00 am, weighed and dried in an oven at $70^{\circ} \mathrm{C}$ to constant weight. Dried feacal were bulked and ground. Feed and feacal were used to determine their respective proximate constituent according to the standard method of (AOAC, 2006) while the metabolizable energy was calculated using the equation; $\mathrm{ME}(\mathrm{kcal} / \mathrm{kg})=37 \mathrm{x} \%$ $\mathrm{CP}+81.1 \times \% \mathrm{EE}+35.5 \mathrm{x} \% \mathrm{NFE}$ (Pauzenga, 1985).

The coefficient of digestibility was calculated using the formula below:

Coefficient of digestibility $=$

Nutrient in feed-Nutrient in feace $x 100$

$$
\text { Nutrient in feed }
$$

\section{Blood constituent evaluation}

At the 8th week of the experiment, birds were fasted overnight so that the serum was cleared of excess fat and protein that could cloud the results. Three (3) birds per treatment replicates of average mean weight were selected for the evaluation of haematological indices and serum biochemical variables. Two (2) $\mathrm{mL}$ of 


\section{Growth performance, blood parameters and production cost of broiler chickens}

blood samples was collected from the birds that were slaughtered using a sharp and cleaned knife, during bleeding; the blood was drained into labelled sterile bottle containing ethylene diaminetetra acetic acid (EDTA) which served as an anticoagulant.

Table 1: Gross composition of the experimental broiler starter diets

\begin{tabular}{|c|c|c|c|c|c|c|c|}
\hline \multirow[b]{2}{*}{ Ingredients } & \multicolumn{7}{|c|}{ Experimental diets } \\
\hline & $\mathrm{T}_{0}$ & $\mathrm{~T}_{1}$ & $\mathrm{~T}_{2}$ & $\mathrm{~T}_{3}$ & $\mathrm{~T}_{4}$ & $\mathrm{~T}_{5}$ & $\mathrm{~T}_{6}$ \\
\hline White maize & 52.60 & 44.71 & 42.08 & 39.45 & 44.71 & 42.08 & 39.45 \\
\hline SOPM & - & 7.89 & 10.52 & 13.15 & 7.89 & 10.52 & 13.15 \\
\hline Soya bean meal & 37.35 & 37.35 & 37.35 & 37.35 & 37.35 & 37.35 & 37.35 \\
\hline Rice bran & 3.25 & 3.25 & 3.25 & 3.25 & 3.25 & 3.25 & 3.25 \\
\hline Blood meal & 2.00 & 2.00 & 2.00 & 2.00 & 2.00 & 2.00 & 2.00 \\
\hline Bone meal & 3.00 & 3.00 & 3.00 & 3.00 & 3.00 & 3.00 & 3.00 \\
\hline Palm oil & 1.00 & 1.00 & 1.00 & 1.00 & 1.00 & 1.00 & 1.00 \\
\hline Herbo-Methionine & 0.15 & 0.15 & 0.15 & 0.15 & 0.15 & 0.15 & 0.15 \\
\hline Premix* & 0.25 & 0.25 & 0.25 & 0.25 & 0.25 & 0.25 & 0.25 \\
\hline L-Lysine & 0.20 & 0.20 & 0.20 & 0.20 & 0.20 & 0.20 & 0.20 \\
\hline Common salt & 0.20 & 0.20 & 0.20 & 0.20 & 0.20 & 0.20 & 0.20 \\
\hline Enzyme & - & - & - & - & + & + & + \\
\hline Total & 100 & 100 & 100 & 100 & 100 & 100 & 100 \\
\hline \multicolumn{8}{|l|}{ Calculated analysis } \\
\hline$* * \mathrm{ME}(\mathrm{Kcal} / \mathrm{kg})$ & 2925 & 2888 & 2876 & 2864 & 2888 & 2876 & 2864 \\
\hline Crude protein (\%) & 23.15 & 23.82 & 22.98 & 22.93 & 23.82 & 22.98 & 22.93 \\
\hline Crude fibre $(\%)$ & 4.38 & 5.19 & 5.46 & 5.77 & 5.19 & 5.46 & 5.77 \\
\hline Ether extract $(\%)$ & 3.63 & 3.94 & 4.04 & 4.14 & 3.94 & 4.04 & 4.14 \\
\hline Lysine $(\%)$ & 1.48 & 1.46 & 1.45 & 1.45 & 1.46 & 1.45 & 1.45 \\
\hline Methionine (\%) & 0.64 & 0.62 & 0.61 & 0.61 & 0.62 & 0.61 & 0.61 \\
\hline Calcium (\%) & 1.04 & 1.04 & 1.04 & 1.04 & 1.04 & 1.04 & 1.04 \\
\hline Available P (\%) & 0.89 & 0.87 & 0.86 & 0.84 & 0.87 & 0.86 & 0.84 \\
\hline \multicolumn{8}{|c|}{ 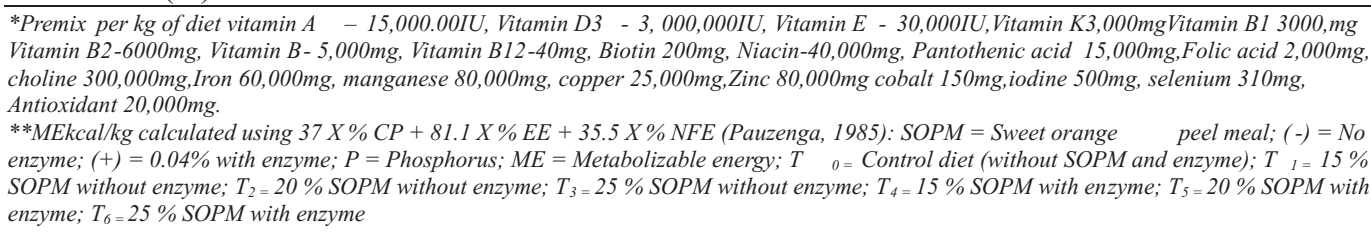 } \\
\hline
\end{tabular}

Haematological indices determined were packed cell volume (PCV), red blood cell count (RBC), white blood cell count (WBC) and haemoglobin concentration $(\mathrm{Hb})$. The improved Nuebaer Haemocytometer method described by Jain (1986) was used to estimate the red and white blood cells, haemoglobin were determined according to Jain (1986). PCV was determined using Wintrobe Microhaematocrit method (Dacie and Lewis, 1991). The determination of the distribution of the various blood cells was done by Shilling method of differential leucocyte counts (Mitruka and Rawnsley,
1977) and mean corpuscular haemoglobin concentration (MCHC), mean corpuscular volume (MCV) and mean haemoglobin concentration (MHC) was computed according to Jain (1986).

A second set of anti-coagulant free bottle tubes were used to collect $3 \mathrm{~mL}$ of blood sample from each bird for serum biochemical analysis. The blood was allowed to clot to obtain serum by allowing the blood sample to stand for 2 hours at room temperature and centrifuged using the High Speed Wintrobes Microhaematocrit for 10 minutes at $2000 \mathrm{rpm}$ to separate the 
Sunmola, Tuleun. and Oluremi

Table 2: Gross composition of the experimental broiler finisher diets

\begin{tabular}{|c|c|c|c|c|c|c|c|}
\hline \multirow[b]{2}{*}{ Treatments } & \multicolumn{4}{|c|}{ Experimental diets } & \multirow[b]{2}{*}{$\mathrm{T}_{4}$} & \multirow[b]{2}{*}{$\mathrm{T}_{5}$} & \multirow[b]{2}{*}{$\mathrm{T}_{6}$} \\
\hline & $\mathrm{T}_{0}$ & $\mathrm{~T}_{1}$ & $\mathrm{~T}_{2}$ & $\mathrm{~T}_{3}$ & & & \\
\hline \multicolumn{8}{|l|}{ Ingredients } \\
\hline White maize & 57.65 & 49.46 & 46.73 & 44.00 & 49.46 & 46.73 & 44.00 \\
\hline SOPM & - & 8.19 & 10.92 & 13.65 & 8.19 & 10.92 & 13.65 \\
\hline Soya bean meal & 32.05 & 32.05 & 32.05 & 32.05 & 32.05 & 32.05 & 32.05 \\
\hline Rice bran & 3.00 & 3.00 & 3.00 & 3.00 & 3.00 & 3.00 & 3.00 \\
\hline Blood meal & 2.00 & 2.00 & 2.00 & 2.00 & 2.00 & 2.00 & 2.00 \\
\hline Bone meal & 3.00 & 3.00 & 3.00 & 3.00 & 3.00 & 3.00 & 3.00 \\
\hline Palm oil & 1.50 & 1.50 & 1.50 & 1.50 & 1.50 & 1.50 & 1.50 \\
\hline Herbo-Methionine & 0.15 & 0.15 & 0.15 & 0.15 & 0.15 & 0.15 & 0.15 \\
\hline Premix* & 0.25 & 0.25 & 0.25 & 0.25 & 0.25 & 0.25 & 0.25 \\
\hline L-Lysine & 0.20 & 0.20 & 0.20 & 0.20 & 0.20 & 0.20 & 0.20 \\
\hline Common salt & 0.20 & 0.20 & 0.20 & 0.20 & 0.20 & 0.20 & 0.20 \\
\hline Enzyme & - & - & - & - & + & + & + \\
\hline Total & 100 & 100 & 100 & 100 & 100 & 100 & 100 \\
\hline \multicolumn{8}{|l|}{ Calculated analysis } \\
\hline$* * \mathrm{ME} / \mathrm{kcal} / \mathrm{kg}$ & 3005 & 2968 & 2955 & 2943 & 2968 & 2955 & 2943 \\
\hline Crude protein $(\%)$ & 21.24 & 21.10 & 21.06 & 21.02 & 21.10 & 21.06 & 21.02 \\
\hline Crude fibre $(\%)$ & 4.08 & 4.95 & 5.24 & 5.53 & 4.95 & 5.24 & 5.53 \\
\hline Ether extract $(\%)$ & 3.62 & 3.93 & 4.03 & 4.13 & 3.93 & 4.03 & 4.13 \\
\hline Lysine $(\%)$ & 1.35 & 1.33 & 1.32 & 1.31 & 1.33 & 1.32 & 1.31 \\
\hline Methionine (\%) & 0.60 & 0.58 & 0.57 & 0.57 & 0.58 & 0.57 & 0.57 \\
\hline Calcium (\%) & 1.04 & 1.03 & 1.03 & 1.03 & 1.03 & 1.03 & 1.03 \\
\hline Available P (\%) & 0.87 & 0.84 & 0.84 & 0.83 & 0.84 & 0.84 & 0.83 \\
\hline \multicolumn{8}{|c|}{ 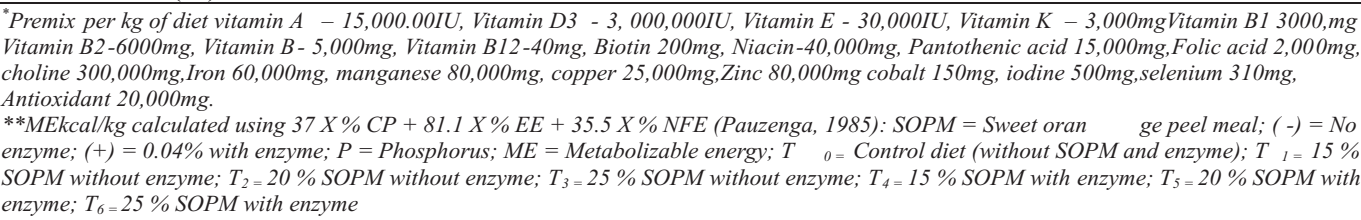 } \\
\hline
\end{tabular}

cells from the serum. Serum total protein, globulin, albumin and urea acid was analysed using Sigma kits according to Benzie and Strain (1996).

\section{Chemical analysis}

Proximate composition of sweet orange peel meal, feeds and feaces were determined using AOAC (2006) methods of analysis, while the metabolizable energy was calculated using the equation; ME $(\mathrm{kcal} / \mathrm{kg})=37 \times \% \mathrm{CP}+81.1 \times \% \mathrm{EE}+35.5$ $\mathrm{x} \% \mathrm{NFE}$ (Pauzenga, 1985).

\section{Statistical analysis}

All data were subjected to Analysis of Variance (ANOVA) using SAS (2008) software package and the significant means were separated using Duncan's Multiple Range Test (DMRT). All statements of significance were based on the 0.05 level of probability.

\section{Results and discussion}

The proximate composition and energy content of sweet orange peel meal and maize used in this study is shown in Table 3. The proximate composition of sweet orange peel meal (Citrus sinensis) had crude protein (CP) and metabolizable energy (ME) contents of $8.20 \%$ and $3079.61 \mathrm{kcal} / \mathrm{kg} \mathrm{ME}$ compared with the CP of $9.20 \%$ and metabolizable energy of $3432.32 \mathrm{kcal} / \mathrm{kg}$ reported by Aduku (2005). The CP of $8.20 \%$ in the peels was lower than $\mathrm{CP}$ in maize, a conventional energy feedstuff with $\mathrm{CP}$ content of $9.25 \%$ (Tuleun et al., 2005), while crude fibre (CF) of 13.30 


\section{Growth performance, blood parameters and production cost of broiler chickens}

$\%$ in the peel was higher than $2.20 \% \mathrm{CF}$ reported for maize. This showed that sweet orange peel meal has comparative energy level with maize, though high crude fibre
$(13.3 \%)$ in the peel may reduce its feeding value in poultry nutrition compared to maize with $1.3 \%$ crude fibre.

Table 3: Proximate composition and energy content of sweet orange (C itrus sinensis) peel meal and maize (\% DM)

\begin{tabular}{lll}
\hline & \multicolumn{2}{c}{ Feedstuff } \\
\cline { 2 - 3 } Nutrients (\%) & ${ }^{1}$ SOPM & ${ }^{2}$ Maize \\
\hline Dry matter & 89.20 & 86.50 \\
Crude protein & 8.20 & 9.10 \\
Crude fibre & 13.30 & 1.30 \\
Ether extract & 4.51 & 4.00 \\
Ash & 6.09 & 2.70 \\
Nitrogen free extract & 67.90 & 83.00 \\
${ }^{3}$ ME kcal/kg & 3079.61 & 3432.32 \\
\hline${ }^{\circ}$ Laboratory Analysis; ${ }^{2}$ Aduku (2005); ${ }^{5}$ Metabolizable energy as determined using Pauzenga (1985), SOPM $=$ Sweet orange peel meal
\end{tabular}

Performance of finisher broiler chickens fed diets containing SOPM with and without enzyme treatment and control diet is shown in Table 4. Initial weight of all groups of broiler chickens ranged between $33.43-33.63 \mathrm{~g} / \mathrm{bird}$. The final body weight ranged from 1.75 to $2.44 \mathrm{~kg} / \mathrm{bird}$. Broiler chickens fed control diet recorded a significantly $(\mathrm{P}<0.05)$ highest final body weight than broiler chickens fed SOPM based diet with and without enzyme treatment.

Table 4 : Effect of dietary sweet orange peel meal with and without enzyme treatment on finisher broiler chickens growth performance

\begin{tabular}{|c|c|c|c|c|c|c|c|}
\hline TRT & AIW (g) & AFI (g/d) & $\mathrm{AWG}(\mathrm{g} / \mathrm{d})$ & AFW (kg) & FCR & PCR & MOT \\
\hline $\mathrm{T}_{0}$ & 33.43 & $86.53^{\mathrm{a}}$ & $42.91^{\mathrm{a}}$ & $2.44^{\mathrm{a}}$ & $2.01^{\mathrm{a}}$ & $0.44^{\mathrm{a}}$ & 2.77 \\
\hline $\mathrm{T}_{1}$ & 33.53 & $78.35^{b c}$ & $34.69^{b}$ & $1.98^{b}$ & $2.25^{\mathrm{b}}$ & $0.48^{b}$ & 0.33 \\
\hline $\mathrm{T}_{2}$ & 33.63 & $69.47^{\mathrm{d}}$ & $30.73^{c}$ & $1.75^{\mathrm{c}}$ & $2.27^{\mathrm{b}}$ & $0.48^{\mathrm{b}}$ & 0.66 \\
\hline $\mathrm{T}_{3}$ & 33.53 & $73.19^{\mathrm{cd}}$ & $30.72^{c}$ & $1.75^{\mathrm{c}}$ & $2.38^{b c}$ & $0.51^{b c}$ & 0.33 \\
\hline $\mathrm{T}_{4}$ & 33.53 & $81.63^{a b}$ & $34.71^{b}$ & $1.98^{b}$ & $2.35^{\mathrm{bc}}$ & $0.50^{\mathrm{bc}}$ & 0.66 \\
\hline $\mathrm{T}_{5}$ & 33.63 & $71.84^{\mathrm{d}}$ & $31.49^{b c}$ & $1.80^{\mathrm{bc}}$ & $2.28^{\mathrm{b}}$ & $0.49^{\mathrm{b}}$ & 0.00 \\
\hline $\mathrm{T}_{6}$ & 33.63 & $73.81^{\mathrm{cd}}$ & $30.02^{\mathrm{c}}$ & $1.73^{c}$ & $2.46^{\mathrm{c}}$ & $0.52^{\mathrm{c}}$ & 0.00 \\
\hline SEM & $0.00^{\mathrm{ns}}$ & $1.80^{*}$ & $1.03^{*}$ & $0.09^{*}$ & $0.05^{*}$ & $0.02^{*}$ & $0.18^{\mathrm{ns}}$ \\
\hline
\end{tabular}

This agreed with the findings of Agu et al. (2010) who reported a significantly $(\mathrm{P}<0.0)$ lower value in final body weight of the broiler chickens fed diets containing SOPM. The result also conformed to that of Ani et al. (2015) who reported that increasing levels of processed SOPM from $5 \%$ to $20 \%$ significantly decreased the average final body weight and weight gain compared with the birds fed control diet. The result is also in line with that of Ojabo and Adenkola (2014) who reported significant differences in final body weight and weight gain of the broiler chickens fed sun-dried SOPM. The significantly $(\mathrm{P}<0.05)$ lower value of body weight and 


\section{Sunmola, Tuleun. and Oluremi}

weight gain recorded in broiler chickens fed SOPM based diets may be associated with the higher crude fibre and other associated intrinsic factors compared to the control. The high crude fibre level contained in the orange peel can precipitate negative effects on broiler performance (Ayed et al., 2011; Soltani et al., 2012). Close (1993) observed a reduction in energy intake with increasing fibre level which reduces both energy utilization and growth. This result was not consistent with the findings of Abdelmoneim et al. (2014) that replacing the yellow corn with orange waste in broiler diet did not cause any significant changes in the broiler chickens performance at all replacement levels with and without enzyme treatment. The higher final body weight and weight gain recorded on broiler chickens fed diet containing $15 \%$ SOPM with and without enzyme treatment collaborated with the findings of Oluremi et al. (2006) that sweet orange rind could replace maize in broiler chickens diet up to $15 \%$ level without any undesirable effect on performance. The result obtained showed that protein conversion ratio was better with the lower levels of dietary SOPM in both treatment groups. The significantly $(\mathrm{P}<0.05)$ higher daily feed intake $(\mathrm{g} /$ bird) recorded in broiler chickens fed control diet compared to the broiler chickens fed sweet orange based diets was in agreement with the report of Ani et al. (2015) that feed intake significantly declined with dietary SOPM inclusion. The result of this study also agreed with the findings of Abbas et al. (2013) on significant reduction in feed intake of broiler chickens at all inclusion levels of dietary SOPM compared to the broiler chickens fed control diet but differed from Abdel-moneim et al. (2014) that replacing yellow corn with orange waste in broiler chickens diet did not cause any significant changes in feed intake of the chickens at all replacement levels with and without enzyme treatment. Ali et al. (2013) also reported a significant influence on feed intake when broiler chickens were fed different levels of dried lemon pulp. The reduction in feed intake could be attributed to a decrease in palatability of the diets with dietary inclusion of peel. Oluremi et al. (2007) reported that citrus fruit peel meal contains residual anti-nutritional substances such as limonene, oxalate, phytate which was found to inhibit growth in poultry, reduced palatability of food and increased excretion of cholesterol (Malinow et al., 1987). Broiler chickens fed control diet had significantly best feed conversion ratio of 2.01 compared to the broiler chickens fed SOPM based diets with and without enzyme treatment. The broiler chickens fed control diet utilized the feed consumed to produce body tissue better than broiler chickens in other dietary groups. This may be attributed to the quality of the feed in terms of palatability, acceptability and nutrient utilisation. The values of daily weight gain and daily feed intake obtained for finisher broiler chickens fed SOPM with and without enzyme were below the expected minimum value of $35 \mathrm{~g}$ and $85 \mathrm{~g}$ respectively, reported by Aduku (2005) except the broiler chickens fed control diet that recorded $42.91 \mathrm{~g}$ and 86.53 $\mathrm{g}$ respectively. The total mortality recorded was 7 (i.e $2.78 \%$ of the total number of birds) and it spread across the different dietary treatments except treatments 5 and 6 with no mortality. Mortality recorded however, was not associated with any traceable cause.

The haematological indices of broiler chickens fed control diet and graded levels of dietary SOPM with and without enzyme treatment are presented in Table 5. The results obtained in this study showed that 


\section{Growth performance, blood parameters and production cost of broiler chickens}

$\mathrm{PCV}, \mathrm{RBC}, \mathrm{WBC}$ and $\mathrm{Hb}$ did not significantly $(\mathrm{P}>0.05)$ differ across the dietary treatments. Significant $(\mathrm{P}<0.05)$ differences were observed in $\mathrm{MCV}, \mathrm{MCH}$, $\mathrm{MCHC}$, lymphocytes, heterophil, eosinophil and monocytes across the dietary treatments. The values of $\mathrm{PCV}$, $\mathrm{RBC}, \mathrm{WBC}$ and $\mathrm{Hb}$ obtained in this study were within the normal range of $27.43 \%$ $37.30 \% \mathrm{RBC}, 1.97 \times 10^{12} \mathrm{~L}-3.75-\times 10^{12} \mathrm{~L}$ RBC, $3.98 \times 10^{9} \mathrm{~L}-10.82 \times 10^{9} \mathrm{~L} W B C$ and $7.50 \mathrm{~g} / \mathrm{dl}$ to $16.04 \mathrm{~g} / \mathrm{dl} \mathrm{Hb}$ reported by Talebi et al. (2005) who investigated a comparative study of haematological values of four different broilers strain (Ross, arbor acres, Cobb and Arian). Non significant $(\mathrm{P}>0.05)$ effect recorded in $\mathrm{PVC}, \mathrm{RBC}, \mathrm{WBC}$ and $\mathrm{Hb}$ may imply that the bone marrows of the birds were functioning normally which revealed the absence of macrocytic and hypochronic anaemia. It also showed that the processing technique which gave rise to SOPM may have reduced its anti-nutritional factors and improve its energy and protein content which according to Cary et al. (2002) improves broiler chicken performance. This also confirmed the fact that haematological traits, especially PCV and $\mathrm{Hb}$ were correlated with the nutritional status of the broiler chicken. $\mathrm{MCH}$ is an indicator of the blood carrying ability of the $\mathrm{RBC}$ and the result obtained could suggest that the birds on all the dietary treatments may be more efficient in performing respiratory function as observed by Longe and Fagbenro (1990). The significant $(\mathrm{P}<0.05)$ differences reported for $\mathrm{MCH}$, $\mathrm{MCV}$ and MCHC across the dietary treatments were within the normal range for healthy broiler chickens as stated by Akinola and Etuk (2015) whose reported $\mathrm{MCH}$ values $24.4 \mathrm{pg}-57.2 \mathrm{pg}$, MCV value $111 \mathrm{fL}-144 \mathrm{fL}, \mathrm{MCHC}$ value $23.4 \mathrm{~g} / \mathrm{dL}-$ $47.2 \mathrm{~g} / \mathrm{dL}$, lymphocyte value of $5.52 \mathrm{x}$
$10^{10} / \mu \mathrm{L}-20.36 \times 10^{10} / \mu \mathrm{L}$, monocytes value of $0.36 \times 10^{10} / \mu \mathrm{L}-1.68 \times 10^{10} / \mu \mathrm{L}$, eosinophil value of $0.6 \times 10^{10} / \mu \mathrm{L}-1.71 \times$ $10 \% / \mu \mathrm{L}$ and heterophil value of $47 \%-100$ $\%$, for broiler chickens. Significant effect reported on lymphocytes, heterophil, eosinophil and monocytes was in line with the findings of Owosibo et al. (2013). This observation indicated that the nutrients were adequately utilized by the broiler chickens and posed no problem to the birds. It explained why the birds were healthy, not anaemic and capable of withstanding stress. Serum biochemical indices of broiler chickens fed SOPM based diets are presented in Table 6. Significant differences $(\mathrm{P}<0.05)$ were observed for all the biochemical indices measured in this study. The values of total protein, albumin, globulin and uric acid recorded in the groups of broiler chickens fed dietary SOPM without enzyme treatment ranged from 4.46 to $4.66,1.33$ to $1.76,2.80$ to 3.06 and 3.30 to $4.03 \mathrm{~g} / \mathrm{dl}$, respectively. The significant similar values recorded on broiler chickens fed SOPM based diet and control diet implied that SOPM with or without enzyme can be confidently used in broiler chickens diet to provide optimum nutrition. The significant differences recorded in serum total protein, albumin, globulin and uric acid across all the dietary treatments showed that there was normal nutrients metabolism. It showed that the diets had better nutritional quality, good amino acid balance; thus, there was absence of muscle degeneration on birds. Imbalances in amino acid in diets had been found to cause elevated blood uric acid concentration (Oladunjoye et al., 2014). The significant $(\mathrm{P}<0.05)$ differences recorded for albumin and globulin showed that there was no liver damage caused by toxicity of dietary substances. This was in line with the finding of Muhammad and 


\section{Sunmola, Tuleun. and Oluremi}

Oloyede (2009) who stated that the values of albumin and globulin are normally low in the blood but becomes high when there is occurrence of liver damage by toxic substances.

The production cost of finisher broiler chickens fed diets containing SOPM with and without enzyme treatment is summarized in Table 7. Feed cost $(\square / \mathrm{kg})$ ranged between $\square 135.19$ to $\square 156.48$ and broiler chickens fed control diet recorded the highest value of $\square 156.48 / \mathrm{kg}$ than broiler chickens fed SOPM based diets with and without enzyme treatment. This was attributed to high cost of maize (a conventional feed ingredient). The feed cost of broiler chickens in SOPM based diets progressively decreased with increased levels of dietary SOPM. This confirmed the findings of Ojabo et al. (2014); Ngiki et al. (2014) and Olaifa et al. (2015) that feed cost per weight gain decreased with increased dietary levels of sweet orange peel meal, cassava root-leaf meal mixture and cassava peel meal based diet respectively on broiler chickens. Broiler chickens fed $20 \%$ dietary SOPM with and without enzyme treatment had the least value of feed consume per weight gain similar to the value recorded for the broiler chickens fed control diet. This was function of low feed consume which was efficiently utilized. The highest Feed cost per chick recorded for broiler chicks fed control diet was as a result of noninclusion of SOPM as a replacement for maize which facilitated the palatability and acceptability of the feed for optimum consumption compared to the broiler chickens fed SOPM based diets with and without enzyme. This was similar to the observation of Ukachukwu (2008) and Akinfala et al. (2011) with cassava plant meal, though without enzyme supplementation. The broiler chicks fed control $1.73 \mathrm{~kg}-1.98 \mathrm{~kg}$. Selling price per broiler chicken was fixed at $\square 650.00$ per kilogram live weight. The highest income and expenses per bird was recorded on broiler chickens fed control diet. The analysis diet recorded the highest feed cost as the percentage of total cost, this was as a result of high cost of feed and total cost of production. The least cost of day old chick as percentage of total cost of production was recorded for broiler chickens fed control diet and was due to the highest total cost of production compared to the broiler chickens fed SOPM based diets with and without enzyme. Break-even analysis for finisher broiler chickens fed diets containing SOPM with and without enzyme treatment is showed in Table 8. The result showed that the highest profit amounting to $\square 436.90 \mathrm{k}$ was made on broiler chickens fed control diet compared to profit made on broiler chickens fed SOPM based diets with and without enzyme which ranged from $\square 172.69 \mathrm{k}-\square 259.44 \mathrm{k}$. The profit per bird decreased with increased levels of dietary SOPM with and without enzyme treatments. The highest income incurred on broiler chickens fed control diet resulted to better cost to benefit ratio compared to broiler chickens fed SOPM based diets with and without enzyme treatment, although, there was no record of loss as the profit was made at all SOPM inclusion levels. 


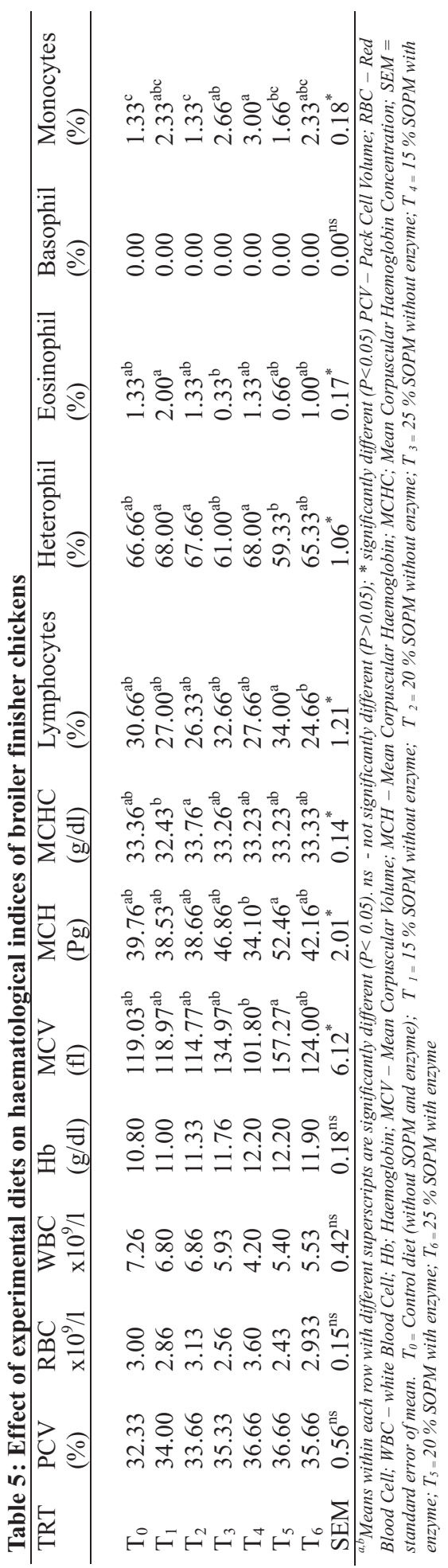




\section{Sunmola, Tuleun. and Oluremi}

Table 6: Effect of experimental diets on broiler finisher chicken serum biochemical indices

\begin{tabular}{|c|c|c|c|c|}
\hline Treatments & Total Protein $(\mathrm{g} / \mathrm{dl})$ & Albumin $(\mathrm{g} / \mathrm{dl})$ & Globulin (g/dl) & Uric acid (mg/dl) \\
\hline $\mathrm{T}_{0}$ & $5.30^{\mathrm{a}}$ & $1.50^{\mathrm{ab}}$ & $3.80^{\mathrm{a}}$ & $2.90^{\mathrm{b}}$ \\
\hline $\mathrm{T}_{1}$ & $4.66^{\mathrm{b}}$ & $1.60^{\mathrm{ab}}$ & $3.06^{\mathrm{bc}}$ & $3.30^{\mathrm{ab}}$ \\
\hline $\mathrm{T}_{2}$ & $4.56^{\mathrm{b}}$ & $1.76^{\mathrm{ab}}$ & $2.80^{\mathrm{c}}$ & $4.03^{\mathrm{a}}$ \\
\hline $\mathrm{T}_{3}$ & $4.46^{\mathrm{b}}$ & $1.33^{\mathrm{b}}$ & $3.03^{\mathrm{bc}}$ & $3.50^{\mathrm{ab}}$ \\
\hline $\mathrm{T}_{4}$ & $4.90^{\mathrm{b}}$ & $1.53^{\mathrm{ab}}$ & $3.36^{\mathrm{b}}$ & $4.00^{\mathrm{a}}$ \\
\hline $\mathrm{T}_{5}$ & $4.50^{\mathrm{b}}$ & $2.13^{\mathrm{a}}$ & $2.36^{\mathrm{c}}$ & $3.60^{\mathrm{ab}}$ \\
\hline $\mathrm{T}_{6}$ & $4.93^{\mathrm{ab}}$ & $1.76^{\mathrm{ab}}$ & $3.16^{\mathrm{ab}}$ & $3.96^{\mathrm{a}}$ \\
\hline SEM & $2.18^{*}$ & $1.02^{*}$ & $1.22^{*}$ & $0.53^{*}$ \\
\hline
\end{tabular}

Table 7: Production cost of finisher broiler chickens fed diets containing sweet orange peel meal with and without enzyme

\begin{tabular}{|c|c|c|c|c|c|c|c|}
\hline \multirow[t]{2}{*}{ Economic Indices } & \multicolumn{6}{|c|}{ Experimental diets } & \multirow[b]{2}{*}{$\mathrm{T}_{6}$} \\
\hline & $\mathrm{T}_{0}$ & $\mathrm{~T}_{1}$ & $\mathrm{~T}_{2}$ & $\mathrm{~T}_{3}$ & $\mathrm{~T}_{4}$ & $\mathrm{~T}_{5}$ & \\
\hline $\mathrm{C}$ of DOC & 110.00 & 110.00 & 110.00 & 110.00 & 110.00 & 110.00 & 110.00 \\
\hline 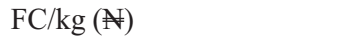 & 156.48 & 143.71 & 139.45 & 135.19 & 144.51 & 140.25 & 135.99 \\
\hline $\mathrm{FI} / 56 \mathrm{~d} / \mathrm{kg}$ & 4.85 & 4.39 & 3.89 & 4.10 & 4.57 & 4.02 & 4.13 \\
\hline $\mathrm{AWG} / \mathrm{kg}$ & 2.40 & 1.94 & 1.72 & 1.72 & 1.94 & 1.76 & 1.68 \\
\hline FC/WG ( $¥ / k g)$ & 315.59 & 324.52 & 315.29 & 321.78 & 339.75 & 319.90 & 334.24 \\
\hline FC/chicks/ 56days/(N) & 758.93 & 630.89 & 542.46 & 554.28 & 660.41 & 563.81 & 561.64 \\
\hline $\mathrm{OPC}(\mathrm{N})$ & 280.17 & 280.17 & 280.17 & 280.17 & 280.17 & 280.17 & 280.17 \\
\hline TCP $(\mathrm{N} /$ chick $)$ & 1147.10 & 1021.06 & 932.63 & 944.45 & 1050.58 & 953.96 & 951.81 \\
\hline CS due to SOPM ( $\$ /$ chick) & - & 128.04 & 216.47 & 204.65 & 98.52 & 195.12 & 197.29 \\
\hline $\mathrm{FC}(\% \mathrm{TCP})$ & 66.05 & 61.79 & 58.16 & 58.69 & 62.86 & 59.10 & 59.01 \\
\hline $\mathrm{C}$ of DOC $(\% \mathrm{TCP})$ & 9.57 & 10.77 & 11.79 & 11.65 & 10.47 & 11.53 & 11.56 \\
\hline
\end{tabular}

Table 8 : Break-even analysis for finisher broiler chickens fed diets containing sweet orange peel meal with and without enzyme

\begin{tabular}{lllllll}
\hline TRT & $\begin{array}{l}\text { ALW } \\
(\mathrm{kg})\end{array}$ & $\begin{array}{l}\text { Selling price } \\
(\mathrm{N}) / \mathrm{kg} / \mathrm{LW}\end{array}$ & $\begin{array}{l}\text { Income } \\
\text { /birds ( })\end{array}$ & $\begin{array}{l}\text { Expenses/ } \\
\text { birds ( })\end{array}$ & $\begin{array}{l}\text { Profit/ } \\
\text { bird ( }) / \mathrm{kg}\end{array}$ & $\begin{array}{l}\text { CST:BFT } \\
(\mathrm{N})\end{array}$ \\
\hline $\mathrm{T}_{0}$ & 2.44 & 650.00 & 1586.00 & 1149.10 & 436.90 & 0.72 \\
$\mathrm{~T}_{1}$ & 1.97 & 650.00 & 1280.50 & 1021.06 & 259.44 & 0.80 \\
$\mathrm{~T}_{2}$ & 1.75 & 650.00 & 1137.50 & 932.63 & 204.87 & 0.82 \\
$\mathrm{~T}_{3}$ & 1.75 & 650.00 & 1137.50 & 944.45 & 193.05 & 0.83 \\
$\mathrm{~T}_{4}$ & 1.98 & 650.00 & 1287.00 & 1050.58 & 236.42 & 0.82 \\
$\mathrm{~T}_{5}$ & 1.80 & 650.00 & 1170.00 & 953.96 & 216.04 & 0.82 \\
$\mathrm{~T}_{6}$ & 1.73 & 650.00 & 1124.50 & 951.81 & 172.69 & 0.85 \\
\hline
\end{tabular}

TRT = Treatment; $C S T: B F T=$ Cost to benefit ratio; $A L W=$ Average live weight $; \mathrm{LW}=$ Live weight; $T_{0=}$ Control diet (without SOPM and enzyme); $T_{1=} 15 \%$ SOPM without enzyme; $T_{2}=20 \%$ SOPM without enzyme; $T_{3}=25 \%$ SOPM without enzyme; $T_{4}=15 \%$ SOPM with enzyme; $T_{5}=20 \%$ SOPM with enzyme; $T_{6}=25 \%$ SOPM with enzyme

\section{Conclusion}

Sun-dried sweet orange peel meal can be used in the diet of broiler chickens up to 25 $\%$ without posing any deleterious effect on the broiler chickens growth performance, blood parameters and production cost.
However, the cost to benefit ratio was compromised.

\section{References}

Abbas. E., Ali, A. A. Q., Alireza, S., Vito, L. and Vincenzo, T. 2013. Effect 


\section{Growth performance, blood parameters and production cost of broiler chickens}

of different levels of dried sweet orange (Citrus sinensis) peel on broiler chickens growth performance. Italian Journal of Animal Science, 2: 11-17

Abdul-Moneim, M. A., Hamady, G. A. A and Motawe H. F. A. 2014. The use of orange waste with and without enzymes in broilers' diets and its effect on their performance, carcass traits and some blood parameters, Research Journal of Animal, Veterinary and Fishery Sciences, 12: 2320 - 6535

Adene, D. F. and Oguntade, A. E. 2006. The structure and importance of the commercial and village-based poultry systems in Nigeria. FAO.

Aduku, A. O. 2005. Tropical Feedstuff Analysis Table. Department of Animal Science, Ahmadu Bello University, Samaru, Zaria, Nigeria.

Agu, P. N, Oluremi, O. I. A. and Tuleun, C. D. 2010. Nutritional evaluation of sweet orange (Citru sinensis) fruit peel as feed resource in broiler production. International Journal of Poultry Science. 9: 684-688.

Agu, P. N. 2006. Nutritional Evaluation of Sweet Orange (Citrus sinensis) Peel as a Feed Resource in Broiler production. Unpublished M.Sc. Thesis. Department of Animal Production, University of Agriculture, Makurdi. Benue State. Nigeria

Akinfala, E. O., Matanmi, O. and Tinuala, J. A. 2011. Nutrient characterization of cassava plant meal and its utilisation by broiler chickens in the tropics. Livestock Research for Rural Development. 23: (11) 201 - 205.

Akinola, L. A. F and Etuk, M. O. 2015. Haematological and Serum
Biochemical Responses of Broilers Fed Varying Levels of Indomie Waste-Based Diets. Journal of Agriculture and Veterinary Science, 38: 66-70

Ali, N. 2013. Evaluation the effects of different levels of dried lemon (Citrus aurantifulia) pulp on performance of broilers and laying hens. International Research Journal of Applied and Basic Sciences 4 (4): 882-888

Ani, A. O., Iloh, E. A. and Akinsola, O. O. 2015. Dietary effect of processed orange peel on growth performance of broiler finisher birds. British Journal of Applied Science and Technology, 9(6): 576-584.

AOAC. 2006. Official methods of analysis. Association of Official and Analytical Chemists. 17th Edition, Washington. DC.Pp 3

Ayed, H. M., Zghal, I. and Rekik, B. 2011. Effect of sepiolite supplementation on broiler growth performance and carcass yield. Reserch Opin Animal Veterinary Science, 1:375-378

Benzie, I. F. and Strain, J. J. 1996. The ferric reducing ability of plasma (FRAP) as a measure of "antioxidant power: the FRAP assay. Analytical Biochemistry, 239(1): 70-76.

Cary, N. C, Williams, P. E. V., Geraet., G., Uzu, A. and Annison, G. 2002. Factors affecting non-starch polysaccharide digestibility in poultry. Rhone Poulen. Animal Nutrition, 42 Aristide Briand BP 10092 164. Antony Cedex, France, 2002

Chapman, H. L. Jr., C. B. Ammerman, F. S. Baler Jr., J. F. Henteges, B. W. and Cunha, J. J. 2000. Citrus feed for Beef cattle. Reviewed Bulletin 751. Department of Animal 


\section{Sunmola, Tuleun. and Oluremi}

Science, Florida Cooperative Extension Service Institute of Food and Agricultural. Science University of Florida, Florida, USA.

Close, W. H. 2003. Fibrous diet for pig. In: M. Gill, O. Owen, G.E. Pollot and T.L.J. Lawrence (eds). Animal Production in Developing Countries. Occasional Publication No. 6. British Society of Animal Production, p. 170.

Dacie, J. V. and Lewis, S. M. 1991. Practical Haematology. $7^{\text {th }}$ Edition, Livinton, (ELBS) Church Hill Publishers. Pp. 7.

Esonu, B. O. 2010. "Animal Nutrition and Feeding: A Functional Approach" Memory Press, Oweri, Nigeria, (11): 198-204.

Ibiyo, L. M. O. and Atteh, J. O. 2005. Response of starter broilers to diets containing graded levels of rice bran with or without palm oil. Nigeria Journal of Animal Production, 32: 39-45.

Jain, C. N. 1986. Schalms Veterinary Hematology $4^{\text {th }}$ Edition, Philadelphia. Lea and Febiger Publishers. Pp. 14-16

Longe, G. and Fagbenro-Byron, J. O. 1990. Composition and physical characteristics of some fibrous wastes and by-products for pig feeds in Nigeria. Bietr. Tropical Landwirtch Zootechnology. 46: 137-144

Malinow, M. R., Concon., W. E., Mclaugblin, P., Tafford, C., Lin, D. S., Livingstone, A. L., Kohler, G. O and McMulty, W. P. 1987. Cholesterol and bile acid balance in Macasa fascicularis. Effects of alfalfa saponin. Journal of Clinical Investment. 67: 156-164.

Mitruka, B. M. and Rawnsley, H. 1977.
Clinical Biochemistry and Haematological Reference values in National Experimental Animals. $1^{\text {st }}$ Edition, New York, USA. Masson Publishing Inc. pp. 106112

Muhammad, N. O and Oloyede, O. B. 2009. Haematological parameters of broiler chicks fed Aspergillus niger fermented Terminalia catappa seed Meal-Based Diet, Global Journal of Biotechnology and Biochemistry, 4(2): 179-183.

Ngiki, Y. U., Igwebuike, J. U. and Moruppa, S. M. 2014. Effects of Replacing Maize with Cassava Root-Leaf Meal Mixture on the Performance of Broiler Chickens. International Journal of Science and Technology 3, (6): $214-218$.

Obi, C. I. 2003. Game production: An alternative beef cattle production in Southern Nigeria. Academic Forum 4:36-40.

Ojabo, L. D and Adenkola, A. Y. 2014. The Growth Performance and Haematology of Cockrel Chicks fed Sweet Orange (Citrus sinenses) fruit peel meal. Annals of Biological Research, 4(10):11-15.

Ojabo, L. D., Oluremi, O. I. A and Uza, D. V. 2014. Effect of feeding sundried sweet orange (Citrus sinensis) fruit peel on pullet chick performance. Research Opinion of Animal Veterinary Science, 4(9): 484-488.

Oladunjoye, I. O., Akinlade, M. and Lawal, Z. 2014. Performance, digestibility, carcass and blood profile of grower rabbits fed baobab (Adansonia digitata) pulp and seed meal. Indian Journal of Fundamental and Applied Life Sciences 4 (2), 2231-6345. 
Olaifa, R. O., Adeyemi, O.A., Oloyede, S. T., Sogunle, O. M., Agunbiade, J. A. and Okubanjo, A. O. 2015. Performance and carcass characteristics of broiler chickens fed graded levels of cassava peel meal based diets. Malaysian Journal of Animal Science. 18(2): 103-112

Oluremi O. I. A., Ngi J and Andrew I. A. 2007. Phytonutrients in citrus fruit peel meal and nutritional implication for livestock production. Livestock Research for Rural Development. Volume 19, article \#8 . retrieved November 4, 2017.

Oluremi, O. I. A., Ojighen, V. O. and Ejembi, E. H. 2006. The nutritive potentials of Sweet orange (Citrus sinensis) rind in Broiler production. International Journal of Poultry Science, 5: 613-617.

Owosibo, A. O., Odetola, O. M., Odunsi, O. O., Adejinmi, O. O. and Lawrence-Azua, O. O. 2013. Growth, haematology and serum biochemistry of broilers fed Probiotics based diets. African Journal of Agricultural Reasearch, 8(41), page 5076-5081

Pauzenga, U. 1985. Feeding parent stock. Zootech International. 4 (5): 22-24.

SAS 2008. SAS Users Guide Statistics, SAS inc. Cary, North Califonia, 2008 edition. Seed Storage Compounds: Biosynthesis, Interactions and Manipulation pp. 175-190. Oxford, UK.

Soltani, A., Pourreza, J., Kheiri, F. and Faghani, M. 2012. Effect of partially substituted barley malt on performance, bone ash, calcium and phosphorus of broiler chickens. Research of Animal Veterinary Science, 2: 133-135
T A C $\begin{array}{lllllllllllll}2 & 0 & 1 & 1 & \text { H o m e } & p \text { a g e }\end{array}$ (http://www.nist.gov/tac/2011). Retrieved August 13, 2008.

Talebi, A., Asn-Razael S., Roseh-chai, R and Sahrael, R. 2005 . Comparative studies on Haematological values of broiler strains (Ross, Arbor acres, Cobb and Anan). International Journal of Poultry Science, 4(8); 573-579

Thackie, A. M. and Flenscher. J. E. 1995. Nutritive value of wild sorghum fortified with leucaena (Leucaena leucocephala Wh. Lam). Bull. Animal Health in Africa, 43: 223275.

Tuleun, C. D., Njike, M. C., Ikurior, S. A. and Ehiobu, N. G. 2005. Laying performance and egg quality of hens fed cassava root meal/brewer's yeast slurry based diets. Production Animal Techniques, 1: 148-152.

Ukachukwu, S. N. 2008. Effect of composite cassava meal with or without palm oil and /or methionine supplementation on broiler performance. Livestock Research for Rural Development, 20 (4): 1023 - 1027

United States Department of Agriculture. 2013. International Egg and Poultry Report.

World Health Organization. 2014. African Region: Nigeria. http://www.who.int/countries/ nga/en/ [accessed August 22, 2014].

Received: $12^{\text {th }}$ September, 2018 Accepted: $24^{\text {th }}$ December, 2018 